\title{
Land valuation in support of responsible land consolidation on Ghana's rural customary lands
}

\author{
Kwabena Obeng Asiama $\odot^{* 1}$, Rohan Bennett $\odot^{2}$, Jaap Zevenbergen ${ }^{1}$ and \\ Seth Opuni Asiama ${ }^{3}$
}

In this paper, we develop a framework for an approach that assigns values to customary rural farmland parcels based on the local people's view of land value to support land consolidation. In a case study of Nanton, Ghana, key land value factors were identified and weighted by the local community. The weights were integrated into the framework that produced a Land Value Index for each farmland parcel. Though the strength of the approach is found in scenario and sensitivity analyses. However, the prime weakness of this framework is that it is more expensive to use than automatic valuation models.

Keywords: Land Valuation, Land Consolidation, Customary Lands, Rural Lands

\section{Introduction}

Land consolidation, in various forms, has been successful in curbing land fragmentation and increasing agricultural productivity in much of the European Union and various Asian countries including China and Nepal. Land consolidation is a land management activity that involves all the procedures for exchanging, rearranging and expanding farmland parcels with the goal of increasing farm productivity (Asiama et al., 2017a). However, despite successful implementation in Europe and Asia, its implementation in Sub-Saharan African customary lands, for example in Malawi (1950) and in Kenya (1954), has been largely unsuccessful (Nothale, 1986; Thurston, 1987). The failure of land consolidation in these areas has been attributed to the direct transfer of land consolidation practices from Europe to Sub-Saharan Africa without due regard to the latter's social, economic, cultural and political situations (Van Dijk, 2003; Asiama et al., 2017a). To resolve this, Asiama et al. (2017b) suggests the development of responsible approaches to land consolidation in Sub-Saharan Africa. Responsible land consolidation uses practices that continuously align the technical and administrative requirements, and the internal processes of land consolidation to the dynamic local societal demands, economic conditions, and cultural and legal requirements (Asiama et al., 2017b).

${ }^{1}$ Faculty for Geo-Information Sciences and Earth Observation - ITC Department of Urban and Region Planning and Geo-Information Management, University of Twente, P.O. Box 217, 7500 AE Enschede, The Netherlands

${ }^{2}$ Swinburne University of Technology, Department of Business Technology and Entrepreneurship, P.O. Box 218, Hawthorn, Victoria 3122, Australia

${ }^{3}$ Department of Land Economy, College of Art and Built Environment, Kwame Nkrumah University of Science and Technology, Kumasi, Ghana

*Corresponding author, email k.o.asiama@utwente.nl;kwabena.asiama@ gmail.com
One of the key stages of land consolidation is the inventory and planning stage where a list of land parcels, based on an inventory of the land parcels, their characteristics and the rights inherent, is created or updated to assist in the comparison of the land parcels (Van Dijk, 2003). Though the use of the market value is recommended by several studies, customary land holders, having a strong cultural and spiritual bond with their lands, are unlikely to trade in their lands. This limits the operation of a land market on customary lands. This results in the inability to use the market value in land consolidation as is does not exist. There is therefore the need to develop an approach to assigning values to the customary rural farm land parcels that is reflective of the local people's view of the land value.

Land reallocation in land consolidation relies on land valuation to describe and assign a value to the farmlands that will be reflective of the local farmers' perception of their farmland values. This will increase their trust in the land consolidation project. Experiences in land consolidation in other parts of the world demonstrate that farmers and land owners usually compare the land value assigned to their farmland parcels to those of similar and neighbouring parcels, and raise objections to the inconsistencies they feel arise (Demetriou, 2016b). This slows down the land consolidation process.

Customary lands present a peculiar case as the social, spiritual and cultural bonds with the land also influence the factors which affect the land value, making it different from lands held in individual ownership. In response, this paper seeks to contribute to the approaches for valuing land in areas without a land market - in order to support land consolidation - by proposing a new framework for valuing customary lands. To this end, this paper will seek to ascertain the current approaches to valuing lands in Ghana and for land consolidation; identify the factors considered when valuing farmland land for land 
consolidation; determine the relevance of these factors in the customary rural setting; determine the requirements for a land valuation approach to support land consolidation for rural customary lands; and identify the strengths and weaknesses of this approach.

In the next section, the paper links land valuation to land consolidation, underscoring the importance of land valuation in the land consolidation process. Section 3 places land valuation within the context of customary lands, with a focus on Ghana. Section 4 follows and delivers the outline of the valuation approach covered in the paper. Section 5 presents the land consolidation case study in which the valuation approach is applied. An overview of the case study area of interest is provided with the valuation factors and available data presented. The results of the case study are also presented and discussed in terms of the strengths and weaknesses of the approach. Section 6 concludes the paper and suggests areas for further research.

\section{Background on land valuation for land consolidation}

Land valuation is the process of estimating the amount at which a parcel of land will be exchanged on a stated basis, having regard to the nature of the asset and the purpose of valuation (RICS, 2017). Land valuation looks at three aspects to determine the process - the nature of the asset, the basis of the valuation and the purpose of the valuation. The purpose of valuation informs the basis upon which the valuation will be undertaken (Awuah et al., 2016). Land valuation draws on the theory of demand and supply, explaining the competitive behaviour of the players of a market to meet their unlimited wants within their limited means and in the context of the limitations of the supply side. Valuation is therefore an attempt to predict the result of meeting demand with supply under specified conditions and factors. These conditions may be objective or subjective, depending on the context within which the valuation is being undertaken. The basis upon which the value is assessed includes the market value, the market rent, worth and fair value. The purposes of valuation among others include sale and purchase, rental, insurance, mortgage, expropriation, and, in this study, land consolidation.

Land consolidation as a land management activity comprises three main stages - the data preparation stage, the inventory and planning stage, and the implementation stage. The inventory stage involves the collecting and/or updating of cadastral and land information records within the land consolidation area and the valuation of the land parcels in the area, to lay the grounds for the planning of the land consolidation works. This includes the identification and adjudication of land parcel boundaries, the determination of the legal status of the parcels, delimitation of the environmental areas and handling of objections. With the underlying principle of land consolidation being that the land holder/farmer should not be worse off after the project, there is the need to ensure that the value of the land received after the project would be equal or higher than the value of the lands held before the project (Demetriou, 2014; Haldrup, 2015). The rule of thumb has been that where the value of a land holder's farm parcel is smaller than it was before the land consolidation project, he may receive monetary compensation, or he may be allocated a larger amount of land to ensure equivalency. On customary lands, where land is a social, cultural and spiritual symbol, the most commonly accepted form of compensation is replacement instead of financial compensation (Asiama, 1981; Asiama, 2015).

Land valuation in support of land consolidation is the process of assigning land values, in monetary terms or in the form of relative scores, to all the land parcels in a land consolidation project area, as well as all the fixtures to those lands including the structures, the trees, etc. (Bullard, 2007; Demetriou, 2014; Branković et al., 2015). However, a critical continuing debate is the basis upon which land valuation for land consolidation should be undertaken. There are currently two bases of value in use for land consolidation: open market value and the agronomic value. The open market value is the land value, expressed in monetary terms, in an arm's length transaction between a willing buyer and willing seller, after suitable marketing and where the parties acted knowledgeably, prudently and without compulsion (RICS, 2017). The agronomic value, expressed on a predetermined scale, is the land value solely based on the agricultural productivity and the soil quality. The basis of value used by various countries depends on the permitted land use and the land market proliferation in the area, with Van Dijk (2003) suggesting the use of soil productivity and agricultural productivity, which he views as the two factors most closely associated with farm land value. Demetriou (2014), however, suggests that the use of the agronomic and soil productivity values is appropriate for areas where housing and other land uses are not possible on agricultural lands, with agriculture being the only possible land use in the area. The approach and the bases for valuing farm lands for land consolidation therefore differ among countries. For some, it is based solely on agronomic value and soil quality, with the valuation process being undertaken by a committee of agricultural experts with inputs from the local farmers (e.g. Germany), or a valuation committee of local farmers (e.g. The Netherlands), using a relative scale with a unique set of categories for each project area (Van Dijk, 2003). In this first group of countries, the productivity of the soil is seen to be more important than all other factors. Where the areas have the same soil quality, then the basis of the comparison will be only the size of the farmland parcel. In Germany, where there is microclimate in hilly areas, these are also taken into consideration. Therefore, for the agronomic value here, the production potential of the farmland parcel is used as a basis of production, with little regard for the contextual factors. The second group bases the land value on the open market value with a local community of experts that determines open market land values (e.g. Moldova and Cyprus) or categorises them into an interval scale with the highest land being 100 (e.g. Denmark) (Demetriou, 2014; Hartvigsen, 2015).

\section{Valuation of customary lands in Ghana}

Customary lands is a multi-dimensional term used by different authors to variously describe other terms including commons, communal lands, traditional lands and indigenous lands (Hardin, 1968; Asiama, 2004; Arko-Adjei, 2011; van Gils et al., 2014; Abubakari et al., 2016). In an 
attempt at a universal definition, several studies have tried to streamline the various definitions from different contexts and regions. In this study, customary lands is defined with three elements: first land that is held on the basis of indigenous tenure rules that have evolved locally; second, the land holding is based on a combination group and individual rights; and third, the rights, responsibilities and restrictions over these lands have arisen as a result of accepted practices based on the customs and traditions of the group (Arko-Adjei, 2011; van Gils et al., 2014b). About $78 \%$ of land in Ghana is held in customary ownership while $20 \%$ is held by the state as public lands, and the remaining $2 \%$ is held in joint ownership by the state and the customary ownership (Kasanga \& Kotey, 2001). The key interests in customary lands are allodial, customary freehold (usufructuary) interests, customary tenancy and customary licences. The allodial interest is held by the group (tribe or family/clan) and managed by the leaders, free from any encumbrances or restrictions, except those emanating from the laws of Ghana. The second, the customary freehold interest, exercised by members of a community, is borne from their inherent rights to use and enjoy the community's lands subject to certain restrictions and responsibilities imposed by the community and the laws of Ghana. The third is the customary tenancy, the land rights obtainable by all persons, indigenes or non-indigenes, based on prior agreed terms based on the area's customs, usually based on sharecropping. Last but not the least is customary licence, which allows for the use of land based on terms agreed upon between the two parties upon the passing of some consideration. Furthermore, the land title registration allows granting of statutory leaseholds on customary lands.

Land valuation methods include the investment method, the sales comparison, the cost method, the residual method and the profits approach, with the first three being the most commonly used in Ghana. These are often used for urban lands and rural residential land parcels as these are mostly held in leaseholds which are traded on the land market (Awuah et al., 2016). However, the customary freeholds, tenancies and licences are not valued much since they are hardly traded, except for cases of compulsory land acquisition (Kidido et al., 2015; Asiama et al., 2017a; Asiama et al., 2017d). Valuation of customary lands further presents a challenge in the process of land valuation, as customary lands are unlikely to be registered due to the layered land tenure, and the low land mobility by which it is characterised. However, this does not mean land mobility is banned on customary lands, as found by Asiama et al. (2017a), where it was found that in one community, lands were rented out on tenancy for a flat rent irrespective of the characteristics of the land. This therefore does not correspond with the conventional neo-classical approach to the value theory, based on the concept of demand and supply and the role of prices in resource allocation (North, 1990; Mooya, 2009). Customary land holders in Ghana view themselves as mere custodians of the land, holding it in trust for future generations. This is characterised by Elias (1956), who describes customary lands as belonging to many who are dead, a few who are living and a countless host yet unborn. However, despite this characterisation, where land is acquired by the government for public purposes or by private companies for large-scale investments, these bodies strive to pay fair and adequate compensation (Anim-Odame, 2011; Kidido et al., 2015; Asiama et al., 2017d). This is done in a manner to ensure that all stakeholders in the land are considered and catered for, as Boydell (2015) demonstrates through use of stakeholder analysis. The approach shows that customary land valuation needs an approach that considers solely the parties involved. Valuation that estimates the consideration for the transfer of land between two identified, knowledgeable and willing parties is based on fair value (GLTN, 2017). In land consolidation on customary lands, the parties involved are the farmers, the families (represented by the family heads), and in some cases, the chiefs. This means that to undertake valuation for the exchange of farm parcels, the local people's perception and understanding of land value will form a major aspect of the process.

\section{The framework for a valuation approach for customary lands}

This section outlines the framework for a valuation approach for customary lands. In determining the Land Value Index (LVI) of the farmland parcels, the new approach seeks to provide a basis for comparison among the farmland parcels (Fig. 1). LVIs are used here instead of scores as used by Branković et al. (2015) and Demir et al. (2002) to allow for continuous values in comparison instead of discrete values. The approach is flexible and context specific, as it can be adapted in any geographic area to support land consolidation because it is possible to tailor the factors and the weights to fit into specific contexts. The approach is knowledge based, using local and expert judgement through value functions. Value functions are mathematical equations reflecting the factors in terms of their desired values, ranging from the best to the worst conditions (Beinat, 1997). The approach measures how far the Land Value Factors (LVFs) deviate from the most suitable condition. LVFs are the individual factors that influence the value of land. Where the parcel will achieve the maximal agricultural outputs, and profits the LVF is denoted by the Score 1 . The most unsuitable conditions for the LVFs are denoted by the Score 0 . The assignment of the scores is done in two ways: (i) through a quantitative method for the continuous variables and (ii) a categorical rating method for discrete variables using the appropriate ordinal scale both through expert and local judgement. Both methods will result in a numerical scale from 0 to 1 . To identify and understand the factors that affect farm land value on rural customary lands, the factors found in previous studies relating to the valuation of other types of land were identified.

A structured interview was conducted with all 72 farmers who farmed in the area of interest to understand their perceptions of the LVFs that were identified, and these factors were weighted according to their importance. The weights assigned, ranging between 0 and 10 , were then standardised. Further semi-structured interviews were conducted with 15 individual farmers, 2 staff of the customary land secretariat, 2 elders of the community, and an agricultural officer, as well as a Focus Group Discussion (FGD) with the leaders of the Farmers' Union of the village. This was done to understand the rankings and the weights assigned to the LVFs assigned by the local farmers. The scores of the factors were standardised 


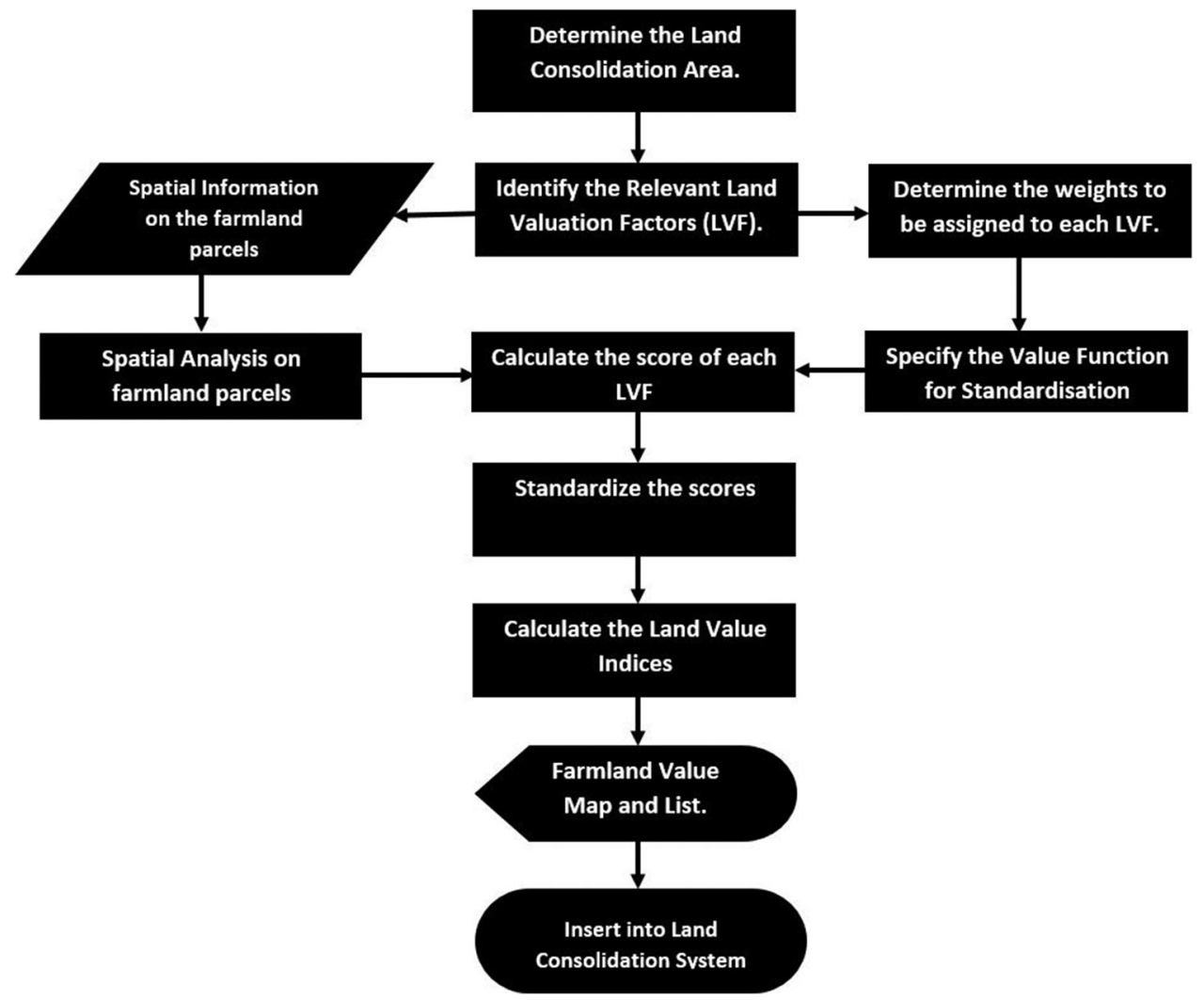

1 Flowchart of the farmland parcel valuation process

using the direct value rating to allow for comparison on the scale. The direct value rating is described in five steps by Beinat (1997). The attributes are first described and then the value range is selected; in this case corresponding to 0 (worst) and 1 (best) respectively. The qualitative characteristics of the value function were then defined (monotonicity, concavity/convexity, etc.). The third step was to specify the values for the selected attribute scores. In this approach, this is done via the bisection technique, i.e. assigning values to selected scores at equal intervals between the maximum and minimum scores. The fourth step was to fit a mathematical equation and/ or a curve through the identified points. In the last step, the function was checked for consistency. The standardised scores $(S)$ were then input into the LVIs Table (Table 1), where each row represented a land parcel $(p)$ and each column represented an LVF (F).

The elements of the Table represent the Land Value Score $(S)$ of a farmland parcel $(p)$ and the factor $(f)$. The LVI for each parcel is calculated by multiplying the score of each factor $\left(S_{p f}\right)$ by the corresponding weight of the factor $\left(w_{\mathrm{f}}\right)$, and summing for each farmland parcel (each row on the table), as depicted in the equation function below:

$$
\mathrm{LVI}_{p}=\sum_{p=1}^{n} S_{f p} W_{f}
$$

\section{The case study: overview, results and discussion}

This section presents a case study in which the framework developed in the previous section is applied and discussed. The section starts with an overview of the case study area of interest and gives details of the area relevant to the study. The development of the land valuation factors follows, and the framework is applied to ascertain the LVFs relevant to the area under study. The LVIs of the land parcels under study are also derived here. Three analyses are conducted and discussed. The first is a scenario analysis, the second is a sensitivity analysis and the third focuses on the influence of Automatic Valuation Models

Table 1 LVIs table for farmland parcels

Land valuation factors (weight)

\begin{tabular}{|c|c|c|c|c|c|c|c|}
\hline Farmland parcel & $F_{1}\left(w_{1}\right)$ & $F_{2}\left(w_{2}\right)$ & $F_{3}\left(w_{3}\right)$ & $F_{f}\left(w_{f}\right)$ & $\cdots$ & $F_{m}\left(w_{m}\right)$ & LVI \\
\hline 1 & $S_{11}$ & $S_{12}$ & $S_{13}$ & $S_{1 f}$ & $\ldots$ & $S_{1 m}$ & $\overline{\mathrm{LVI}_{1}}$ \\
\hline 2 & $S_{21}$ & $S_{22}$ & $S_{23}$ & $S_{2 f}$ & $\ldots$ & $S_{2 m}$ & $\mathrm{LVI}_{2}$ \\
\hline 3 & $S_{31}$ & $S_{32}$ & $S_{33}$ & $S_{3 f}$ & $\ldots$ & $S_{3 m}$ & $\mathrm{LVI}_{3}$ \\
\hline$p$ & $S_{p 1}$ & $S_{p 2}$ & $S_{p 3}$ & $S_{p f}$ & $\ldots$ & $S_{p m}$ & $\mathrm{LVI}_{p}$ \\
\hline$\ldots$ & $\ldots$ & $\ldots$ & $\ldots$ & $\ldots$ & $\ldots$ & $\ldots$ & $\ldots$ \\
\hline$n$ & $S_{n 1}$ & $S_{n 2}$ & $S_{n 3}$ & $S_{n f}$ & $\ldots$ & $S_{n m}$ & $\mathrm{LVI}_{n}$ \\
\hline
\end{tabular}


(AVMs). Sensitivity analysis is used to understand the impact of a range of variables on the outcome by isolating the variables and recording the range of outcomes (Rajaonson \& Tanguay, 2017; Zahedi-Seresht et al., 2017). With scenario analysis, a situation is determined, and all the variables are altered to align with that situation. The approach is also briefly compared to the current AVMs available to understand its strengths and weaknesses.

\section{The area of interest}

The study takes place in a farming village called Nanton in northern Ghana where there is a need for land consolidation (Asiama et al., 2017a). Nanton is located $18 \mathrm{~km}$ from Tamale, the regional capital, and $646 \mathrm{~km}$ from Accra, the national capital (Fig. 2). Nanton is also the seat of the larger Nanton Traditional Area. The village lies in the Guinea Savannah grassland vegetation zone, characterised by vast grassland, dotted with shrubs (Fig. 3). The area of interest for this study lies on the east of Nanton village. It has an average height of about $170 \mathrm{~m}$ above sea level and lies along the Regional Highway 90, which connects Tamale and Karaga, a district capital. It is about 300 hectares ( $3 \mathrm{sq} \mathrm{km})$ in size and the main land use is crop farming, with a few farmers undertaking cattle rearing. For the purposes of this case study, the area of interest is the land consolidation area.

The area of interest comprises 230 farmland parcels, with an average size of 1.29 hectares (Fig. 3). The base

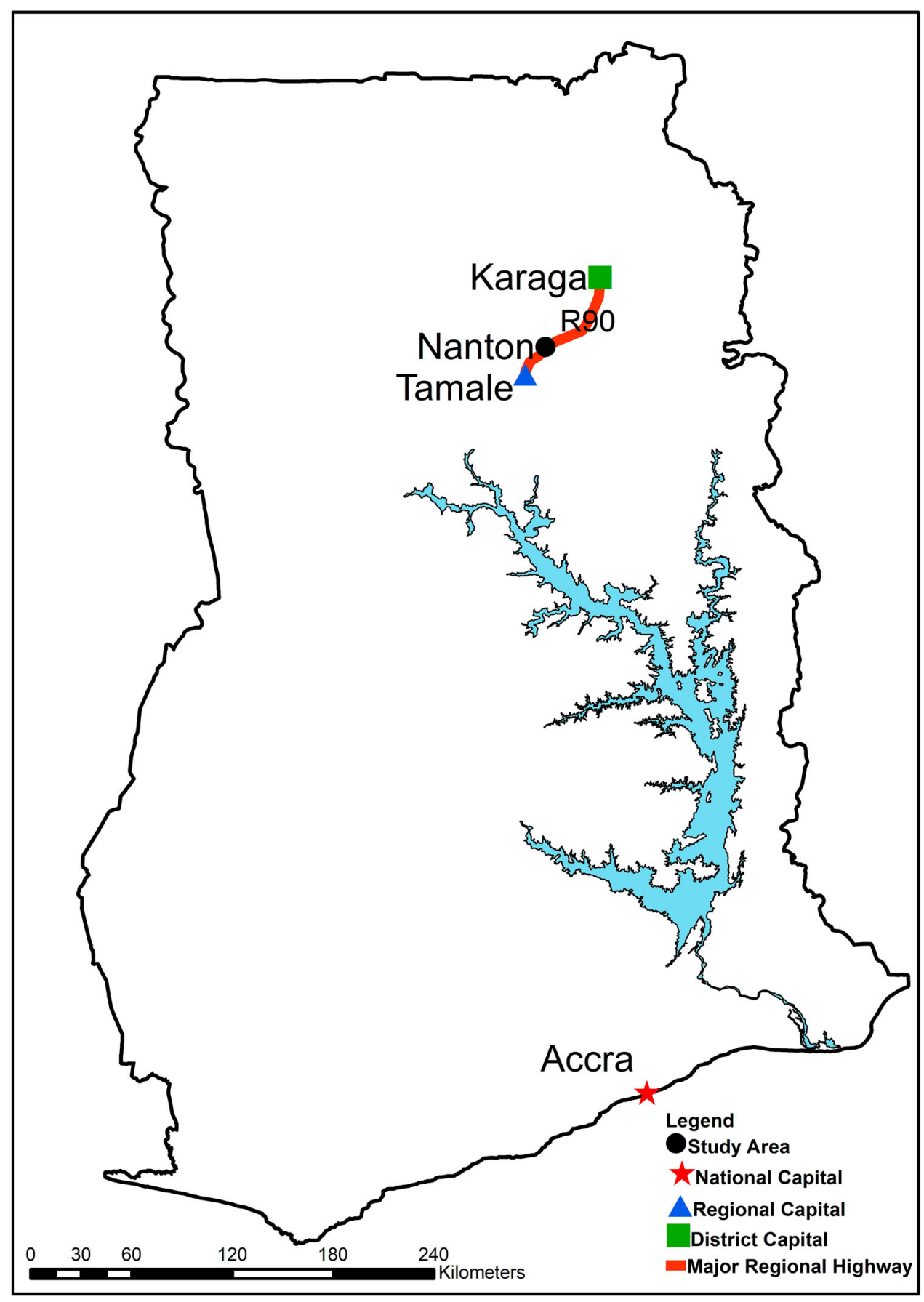

2 Map of Ghana showing the area of interest and other areas relevant to the study 


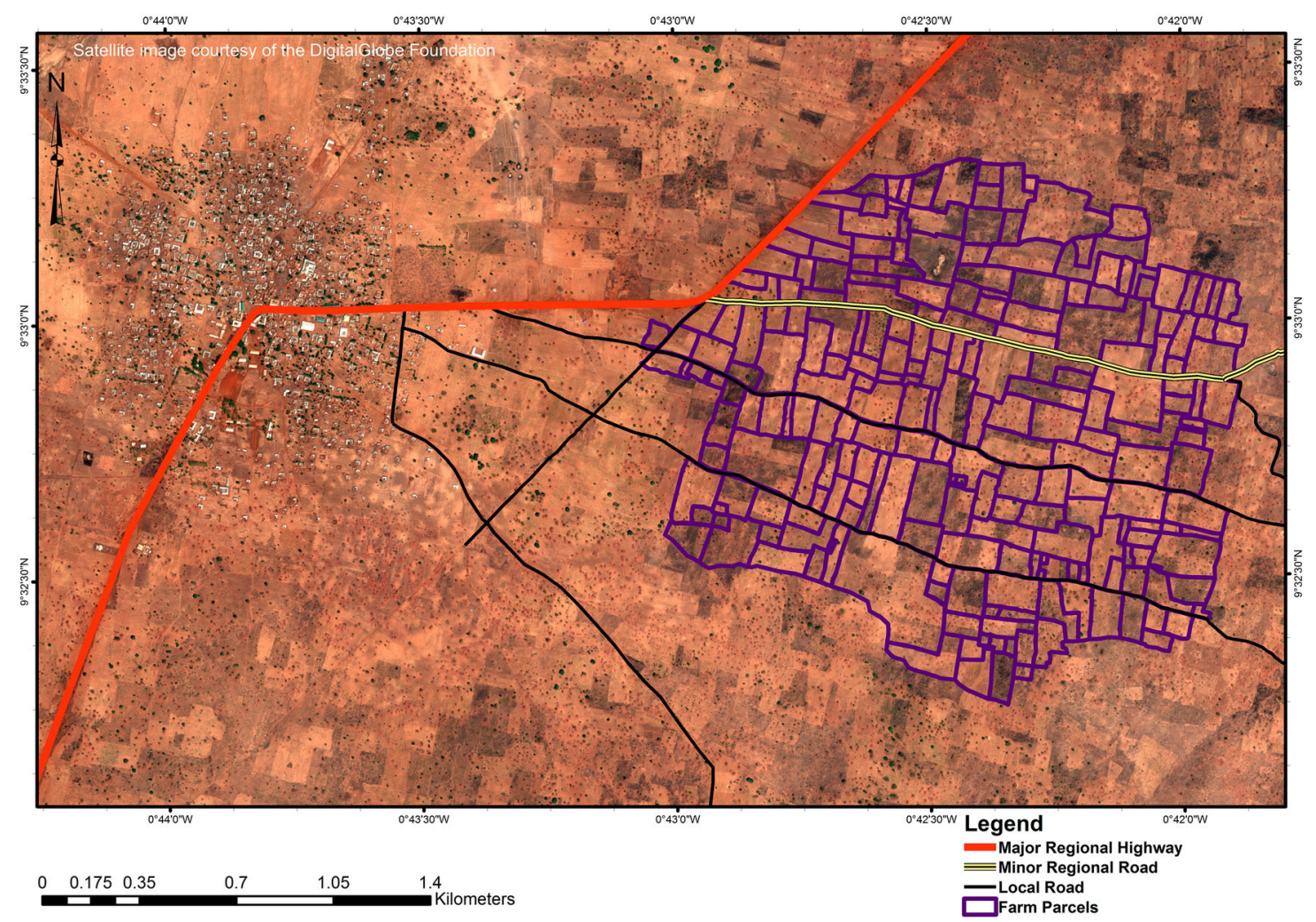

3 The area of interest (with farm boundaries denoted by purple lines) and the Nanton village

map used is a land rights map collected using the Participatory Land Administration approach developed in Asiama et al. (2017b), which seeks to harness the push of emerging technologies to meet the current societal needs, balancing the traditional government-led topdown land administration with the emerging crowdsourced bottom-up land administration. Other information was collected from the Survey Division of the Lands Commission and the Savannah Agricultural Research Institute in Tamale.

\section{The land valuation factors}

To derive the factors that influence rural customary land values, the LVFs used in previous studies such as Branković et al (2015), Clark (1973), Demetriou (2016b), and Wyatt (1996) are examined. In all, 13 factors are found to be relevant to the valuation of rural customary lands for land consolidation from the existing literature and the interviews (Fig. 4). The LVFs have been generally classified by Wyatt (1996) into two groups - the internal and external group of factors. The internal group of factors are those integral to the land parcel such as the physical characteristics of the property, the legal conditions and the farm productivity. The second group relates to factors that are external to the property such as the locational attributes, planning scheme and provision of services. These factors are assessed using specific factors (under them) to measure their impacts. The physical characteristics include the size, shape, elevation, slope and the soil type of the farm parcels. The legal conditions deal with the land tenure arrangements, while the agricultural productivity is determined by the soil quality and the soil type. Under the external group of factors, locational attributes are determined by the access to roads, proximity to perennial water sources and proximity to the town square.

\section{Internal factors}

The internal factors are viewed as the more important factors as they directly affect the outputs from the farms (Nzioki et al., 2013; Branković et al., 2015; Awuah et al., 2016). The size of the farm parcel determines how much can be grown on it. As a result, all other things being equal, the larger the farm parcel, the higher the output and the value. The shape of the farm parcel is also relevant, especially in terms of scaling up the farm operations through mechanisation of cultivation and harvesting activities to make optimal use of the farm parcel (Migot-Adholla et al., 1991; Van Dijk, 2003; Bullard, 2007). This is especially relevant for areas like Nanton where the mechanised farming equipments are hired, and the owners give them out to farmers who own larger and more regularly shaped farms first (FGD with local Farmers' Union).

In the assessment of the optimum parcel shapes for agricultural production, several indices exist, such as the Shape Index and the Fractal Dimension used by Aslan et al (2007) and Gonzalez et al. (2004). These indices are, however, not sensitive to their regularity, resulting in regular and irregular parcels having similar indices, since the area and perimeter are the factors considered. This paper therefore uses the Parcel Shape Index (PSI) developed by Demetriou et al. (2013), which integrates the perimeter, the acute angles, the reflex angles, boundary points, compactness, and regularity as the geometric parameters and is independent of the size of the farmland parcel. The result of this 


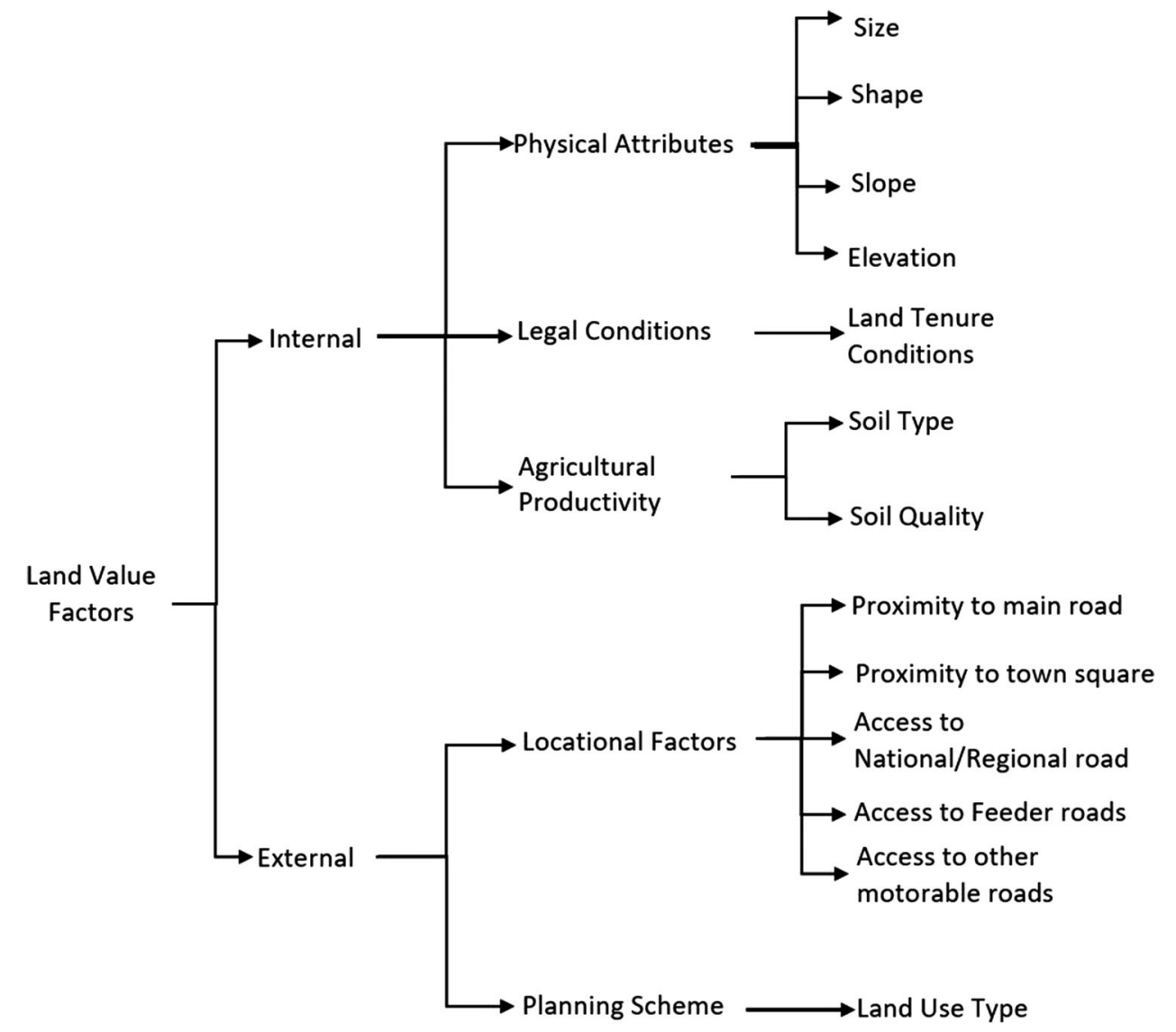

4 Summary of LVFs (adapted from Wyatt, 1996)

index is a value between 0 and 1 for each parcel, with 0 representing the worst shaped parcels and 1 representing the best shaped parcels; in this case a rectangularshaped parcel with the ratio of the sides being $2: 1$. The slope of the farm parcels also affects the mechanisation costs in terms of the machine power and fuel needed for the farm operations (FAO, 2008). Furthermore, being a guinea savannah grassland, with a risk of erosion, the slope also determines how much will be spent on erosion control. The elevation of the farm parcels in general affects the types of crops grown, as well as the time of planting and harvesting (Netting, 1972).

The local farmers expressed a slight indifference over the effect of the elevation on their farming activities, assigning a low weight to this factor (Interview with local farmers). The type of soil also influences the farmland value as it also determines the type of crops that can be grown, as well as how much money will be spent on growing the crops. The soil in the area of interest is classified as Ferric Luvisols by the Savannah Agricultural Research Institute of Ghana.

The land tenure arrangements in the traditional area comprise the allodial title, which is considered to be the most secure interest by the local people and is held by the stool/skin in trust for the people, the customary freehold (or usufructuary interest), the tenancy and the farming licence, considered the least secure (Interview with local farmers and local elders). The customary freehold is, however, the highest interest and most secure interest an individual may hold, which burdens but does not extinguish the allodial title held by the larger community. The holder has the right to the use and enjoyment of the land during his lifetime and may pass it to his heirs through the normal rules of succession. The tenancy is held off the customary freeholder and is irrevocable and inheritable, unless terms stating otherwise have been expressly agreed upon (Arko-Adjei, 2011). There are also farming licences given by the customary freeholder to another farmer to farm on his land for a farming season for a fee. The licenced farmland was deemed to be the least desirable interest in land in the traditional area by the local farmers (FGD with local farmers' union). The scores for the land tenure are calculated as the customary freehold being 1 , the tenancy as 0.5 and the farming licence being 0 as the least desired. With respect to the soil quality and productivity, the local farmers keep very little information on their outputs. However, they determine the productivity of a farm by the crops being sown (FGD with local farmers' union). Where the productivity is low, farmers try to improve the fertility by planting leguminous crops such as groundnuts and beans. The farmers with inadequate resources leave their least productive or desirable farm parcels bare and cultivate their other farm parcels (Interview and FGD with the farmers). The scores for the farm productivity are therefore assigned according to the crops grown on the farms as this is how the farmers themselves determined the productivity.

Farms with non-leguminous crops were assigned 1 as they were seen to be the most fertile. Farms with leguminous crops were assigned 0.5 , and bare farmlands 

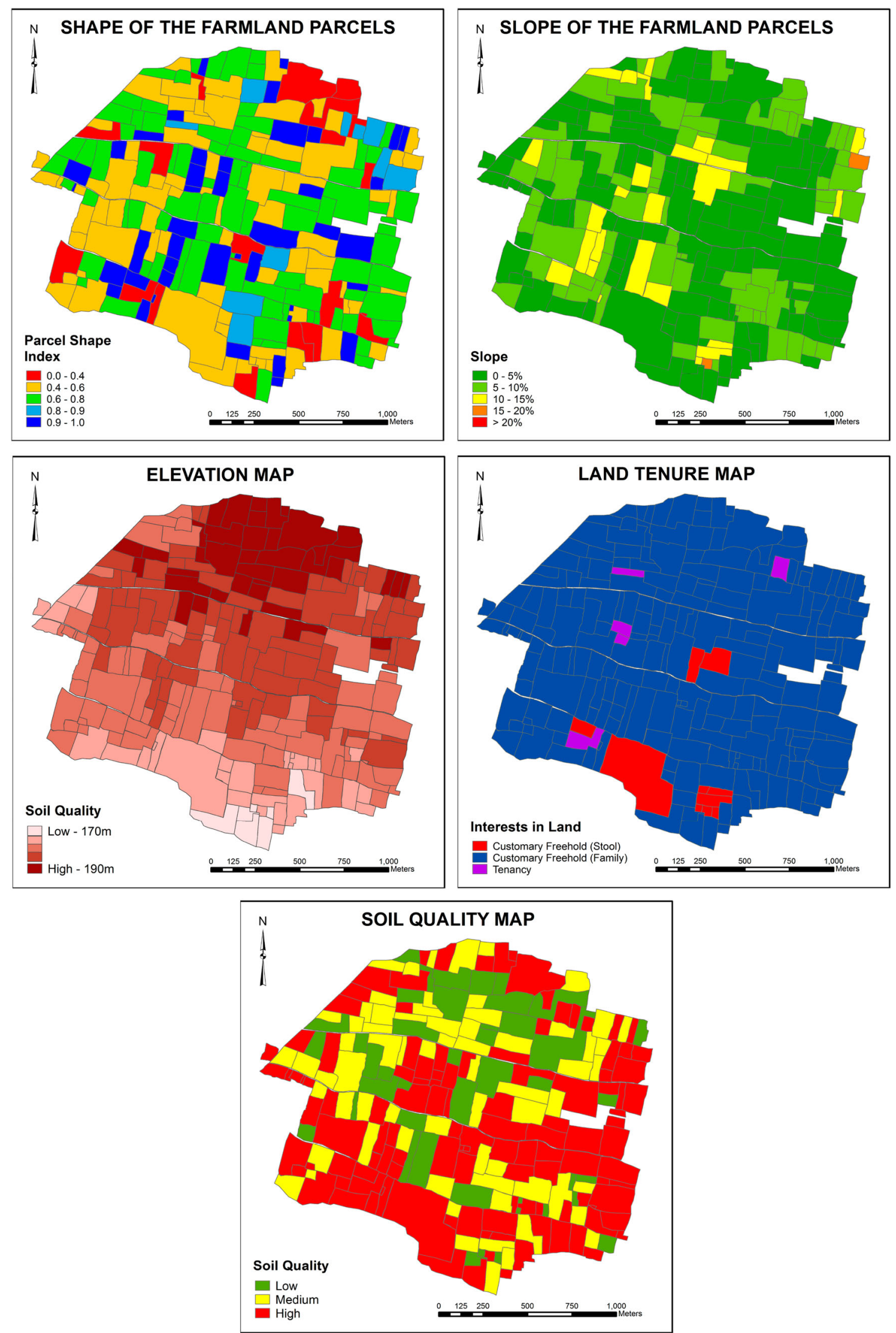

5 The physical attributes and legal conditions in the area of interest

were assigned 0 . Though the weights attached to the individual LVFs were determined by the local people, the scores for five of the LVFs, shape, slope, elevation, soil type and soil quality were determined through technical processes and expert judgement, not by the local farmers (Fig. 5). 

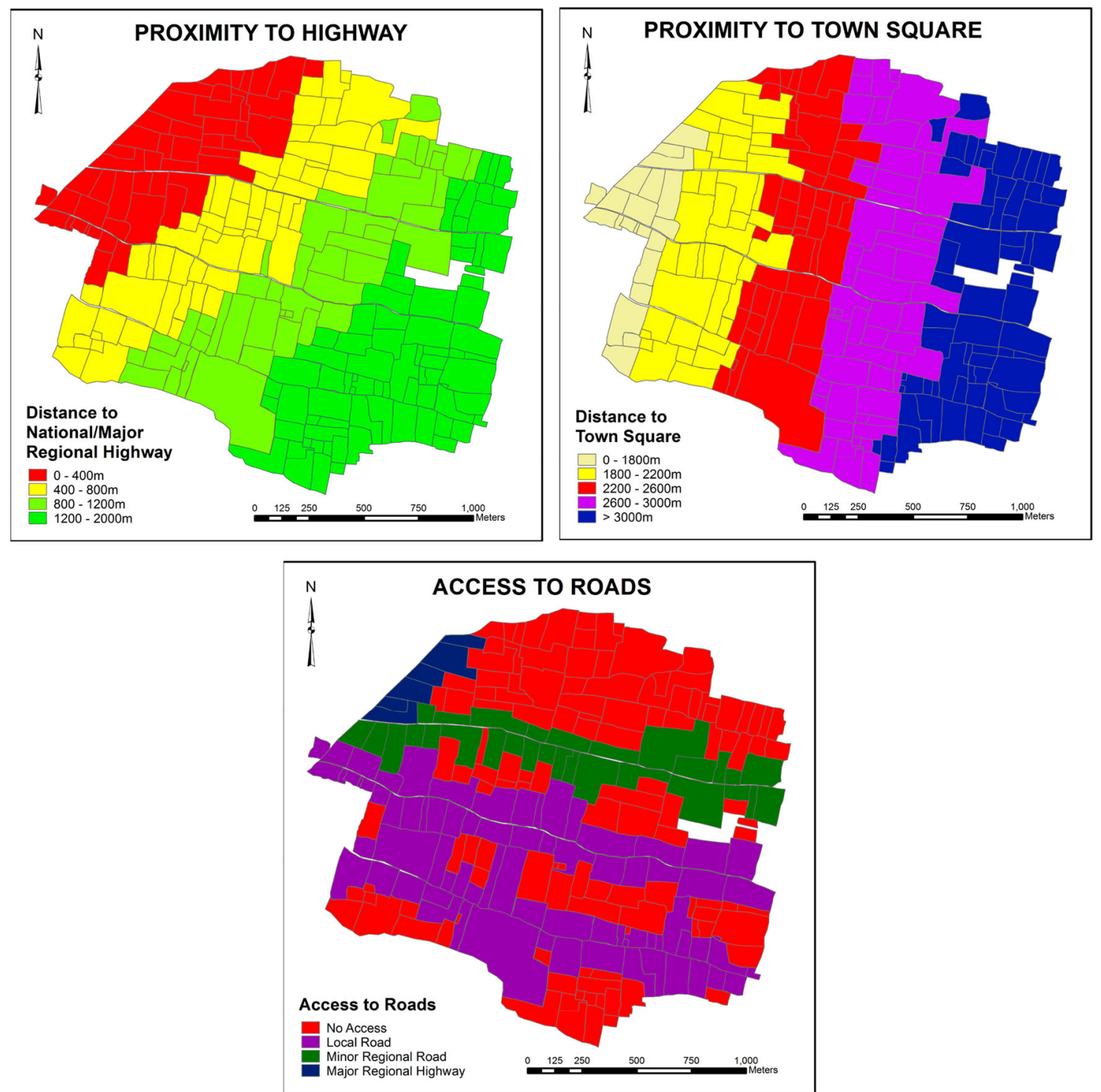

Locational factors in the area of interest

\section{External factors}

The factors external to the land parcels are essential to determine how they interact with other parcels as well as the availability of services in their locality (Fig. 6).

The locational characteristics of the property are considered to be the most important group of factors here, however, other factors such as the land use planning scheme in the area also influence the land value. With respect to locational attributes, access to roads was identified as the most crucial factor influencing land value because the transportation of the harvested crops is a general problem in the area. The closer a farmer is to the road, the easier it is for his food crops to be transported to the market square using a vehicle. Short of this, food crops must be carried on a head pan to the road or even to the market square. Three types of roads are found in the area of interest. The first is a major regional highway, the R90, which connects district capitals to regional capitals and the national highway. The R90 which borders the area of interest, connects Tamale, the regional capital to Karaga, a district capital. The second type of road is the minor regional highways that serve as feeder roads, connecting small towns and villages to the national and major regional highway system. The third type of roads is the locally developed roads that ease the transportation problems in the locality. These roads are not usually tarred. Aside from the three types of roads, there are also footpaths that allow for access to the farms by foot, bicycle or motorcycle. However, these footpaths, according to the local farmers, bare little relevance to their view of the farmland values, so they are not used in the analysis for value.

The proximity of the farmland to the national and major regional highway is a factor suggested by the local farmers as important and independent to road access. The proximity to the highway was deemed important because it provided a market for the farmers who could stand along these roads and sell their produce to passers-by, without having to transport them to the market. The proximity of the farmland parcel to the town centre is also important as this is where the market square is located, therefore the farms located closer to it are considered to have a higher value. With respect to the planning scheme of the area, this determines the likelihood of the farm remaining in the current land use in the future, and thus affecting the value of the land parcel as a farm. 
Table 2 Weights assigned to the LVFs according to the scenarios (Scenario 0 - weights determined by local community; Scenario 1 - equal weights; Scenario 2 - internal factors weighed higher than external factors; Scenario 3 - weights assigned in an inverse order to those assigned by the local community)

\begin{tabular}{lcccc}
\hline LVF & $\begin{array}{c}\text { Scenario } \\
\mathbf{0}\end{array}$ & $\begin{array}{c}\text { Scenario } \\
\mathbf{1}\end{array}$ & $\begin{array}{c}\text { Scenario } \\
\mathbf{2}\end{array}$ & $\begin{array}{c}\text { Scenario } \\
\mathbf{3}\end{array}$ \\
\hline Land tenure & 10 & 10 & 10 & 2 \\
Proximity to & 8 & 10 & 10 & 2 \\
town square & & & & \\
Road access & 8 & 10 & 10 & 2 \\
Soil quality & 7 & 10 & 10 & 3 \\
Shape & 6 & 10 & 10 & 5 \\
Proximity to & 5 & 10 & 10 & 6 \\
main road & & & & 7 \\
Slope & 3 & 10 & 1 & 8 \\
Land use & 2 & 10 & 1 & 8 \\
Soil type & 2 & 10 & 1 & 10 \\
Elevation & 2 & 10 & 1 & \\
\hline
\end{tabular}

However, the whole area is designated to be a farming area, and therefore the land use of the area is the same. The weights attached to these LVFs are displayed in Table 2.

The LVIs of the area of interest according to the LVFs are displayed in Fig. 7, with a mean LVI of 0.68, a minimum of 0.8 and a maximum of 0.94 .

\section{Scenario analysis: the impact of the weights on the LVI}

The strength of the new approach is considered to be the direct involvement of the local people, in not just the selection of the LVFs but also the weighting of the factors. This approach is needed because the area of interest is without a land market to provide for a basis of comparison to reach a market value. Therefore, the perception of the local farmers and other relevant stakeholders is mostly embodied in the weights attached to the land valuation scores. Therefore, to ascertain how significant

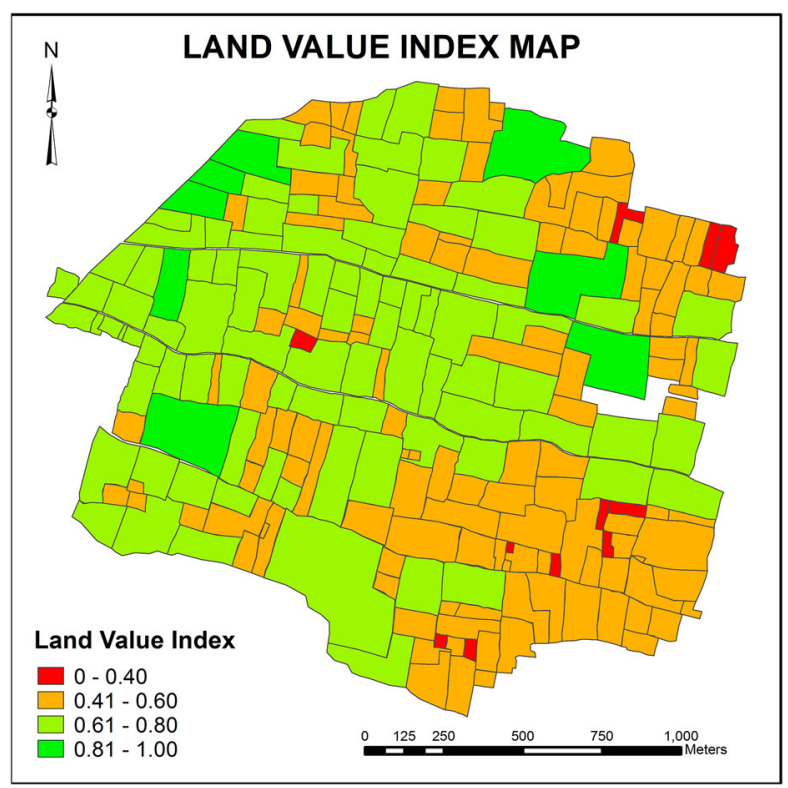

7 LVls of the farmland parcels the weights are in determining the LVI, three scenarios are simulated with respect to the weights, and are compared to scenario 0 , the LVIs determined by the weights assigned by the local community and experts.

A further strength of the approach stemming from the assignment of weight in the process is the transparency and participation it affords the local people. Other approaches that use AVMs as suggested by Branković et al., (2015) and Demetriou (2016a) that rather use multiple regression and geographically weighted regression, present approaches that do not involve the local people. They also present cases that cannot be analytically explained to local farmers. However, this approach has been developed based on the local farmers' understanding of their land value, and hence their involvement from the first to the last step. The success of land consolidation relies on the trust the local farmers and people have in the process. Therefore, first if their understanding about the process is low, it is likely that they will not be satisfied with the end result and will object or reject the project. Second, the involvement of the farmers will produce a result that aligns best with the views of the local farmers on the value of their farmlands.

In the first scenario, all the LVIs are assigned equal weights. In the second scenario, the weights are assigned in line with the Dutch and German Agronomic approach, which gives priority to the internal LVFs which are assigned higher weights and prioritises the internal factors. In the third scenario, the weights are assigned in an inverse order to those assigned by the local community, with respect to the LVFs. The resulting average LVIs for the four scenarios are $0.68,0.70,0.74$ and 0.75 respectively. Though these results show that the different combinations of the weight do not yield any significant difference in the average LVIs, however, a closer look at the individual LVIs (Fig. 8) shows otherwise. With an average difference between the LVIs of scenario 0 and scenarios 1,2 , and 3 respectively being $0.02,0.06$ and 0.07 ; and a minimum and maximum difference of 0.01 and 0.26 respectively, at least an LVI of 0.05 is needed for the parcel to be classified at a higher land value grade with different comparable parcels. Therefore, the differences realised from scenarios 2 and 3 are enough for a change in the land value grade. Furthermore, the individual LVIs show that at least 160 LVIs of scenarios 2 and 3 have a difference of more than 0.05 from scenario 0 . Therefore, the weights have a significant effect on the LVIs in the area of interest.

\section{Sensitivity analysis: the effect of individual weight changes in the LVIs}

The sensitivity of the LVI shows that in general the LVI is not significantly sensitive to changes in the weight of the individual factors. This is shown in Fig. 9, where a $100 \%$ increase or decrease in the weight of land tenure resulted in an average of $8.82 \%$ change in the LVIs. The sensitivity of the LVI is the maximum percentage difference in the absolute values of the overall LVI for the minimum to maximum change $(0-100 \%)$ for either an increase or a decrease in the weight of the factor. The result indicates a stability in the indices, and reliable decisions can therefore be taken based on them. Fig. 9 shows land tenure and road access as the two most sensitive factors to the decrease and increase in weights respectively, with 


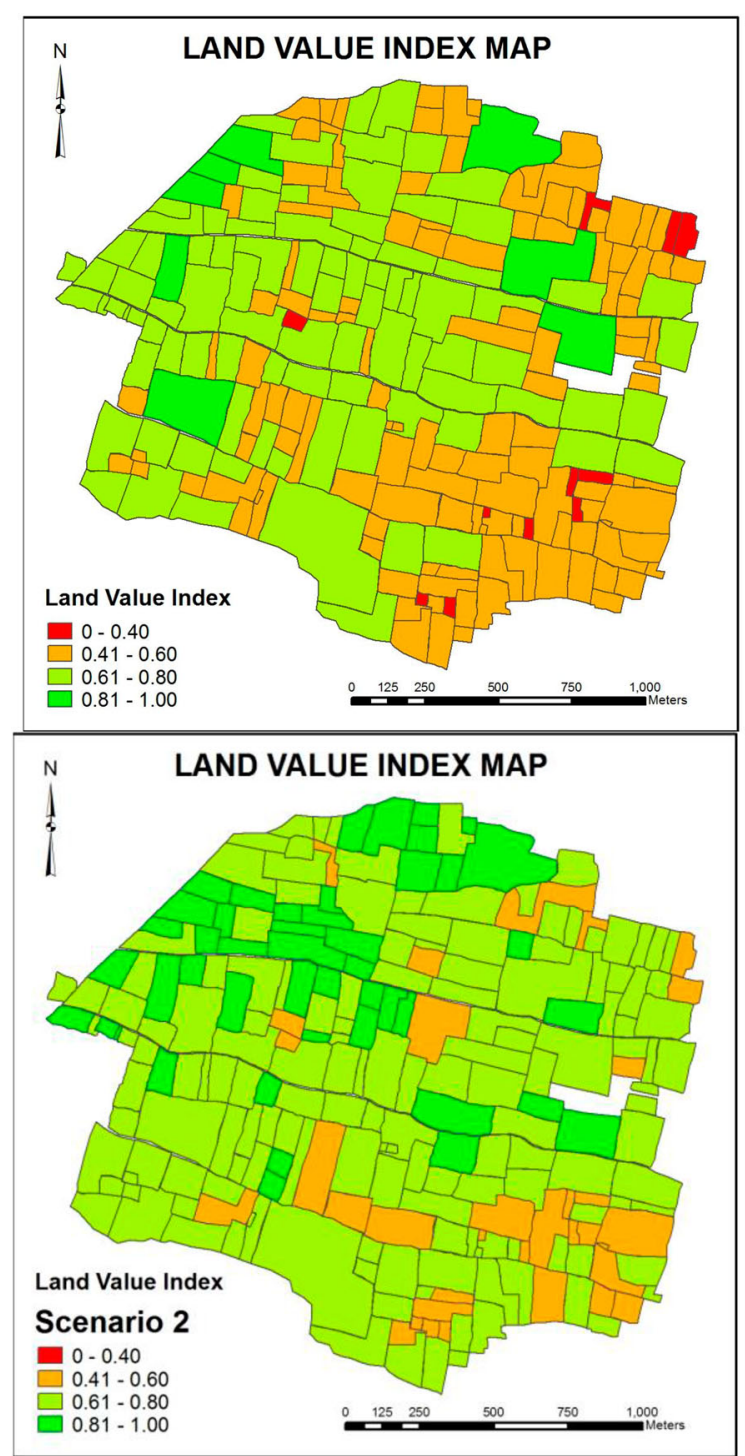

8 The comparison of the four scenarios

soil quality being only sensitive to the decrease in weight. Elevation is neither sensitive to increases nor decreases.

The shape, slope, soil type, proximity to main road and town square, and the land use are all slightly sensitive.
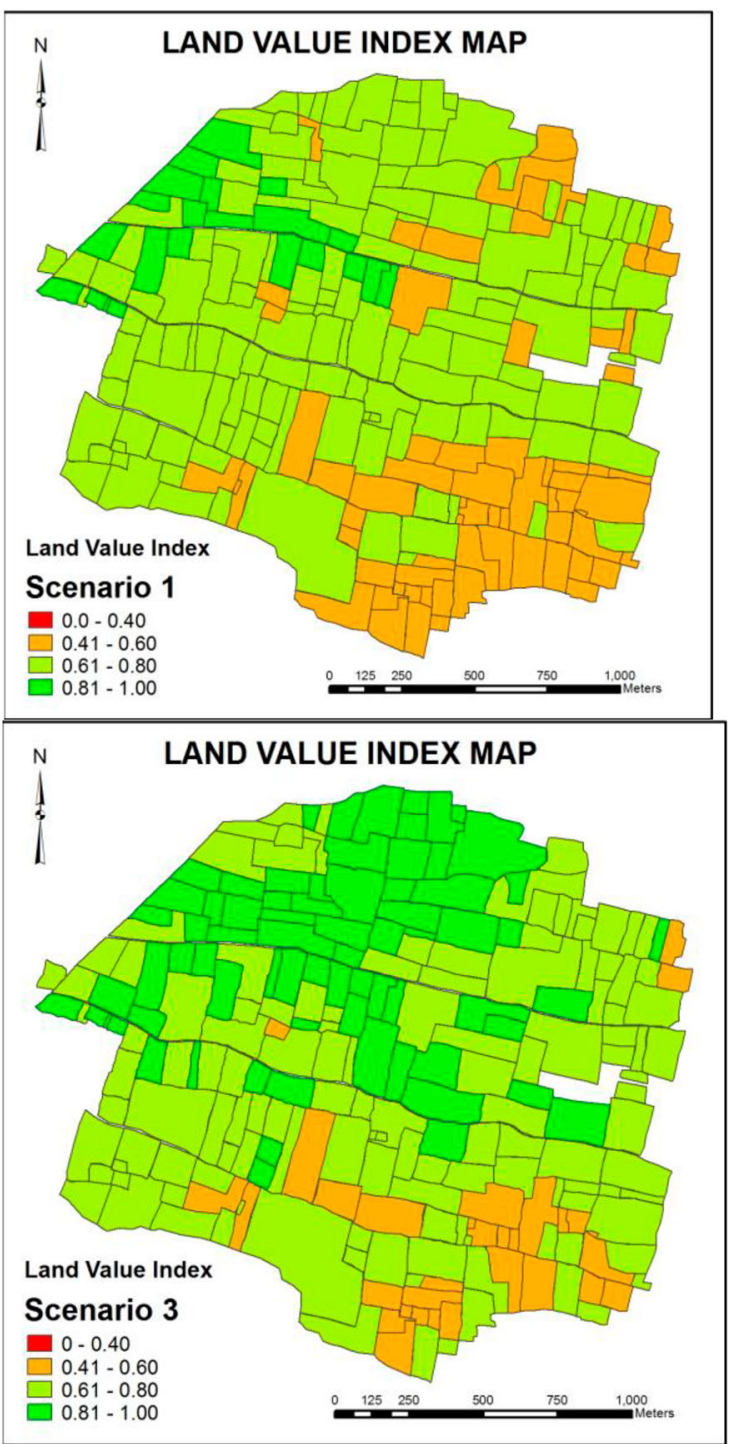

Therefore, land tenure and road access are the most critical LVFs, with both having positive and negative impacts on the LVI. This means that the more important these factors are, the higher the LVI, and vice versa. The LVI is not

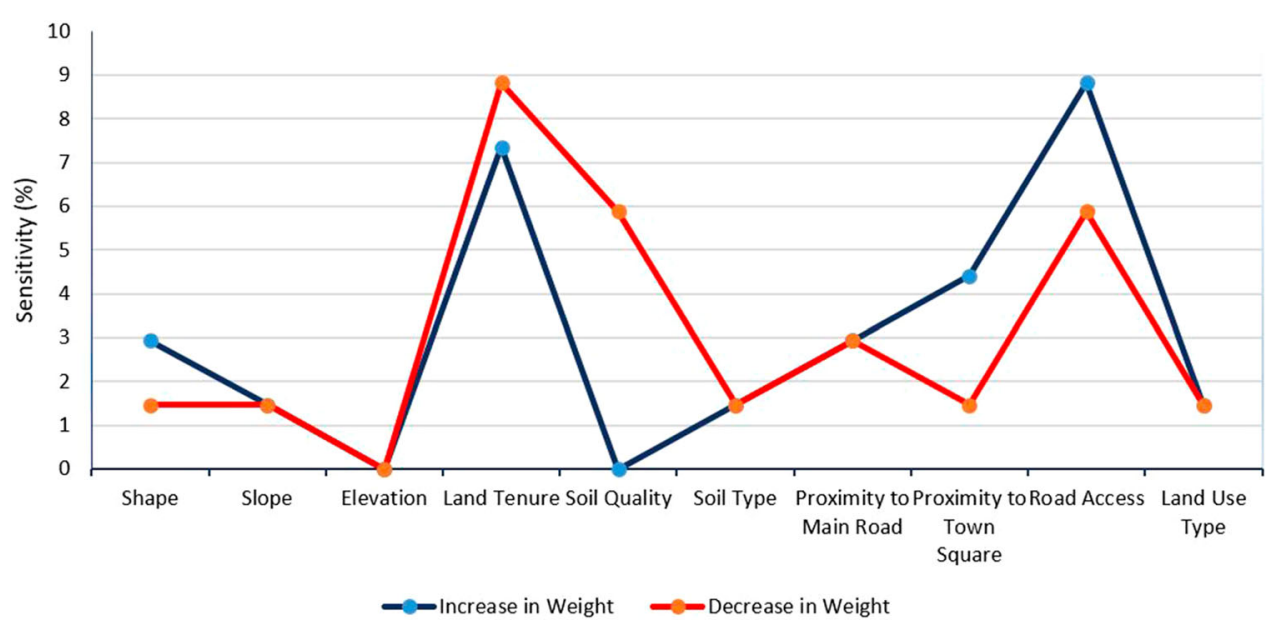

9 The sensitivity of the overall LVI for either an increase or decrease in the weight of each LVF 
sensitive to a change in the weight of the elevation. This shows the elevation's independence of the weights. This finding shows that some factors such as the shape, slope and soil type of the parcels have a high influence on the LVIs (though they may have low sensitivity), whereas land tenure, road access, soil quality and elevation have less impact.

\section{The influence of AVMs}

The main weakness of the framework in this paper is the drive towards AVMs, especially with regards to land consolidation (Demetriou, 2016b). These approaches harness multiple regression analysis and geographically weighted regression in a GIS environment. AVMs represent a wider trend in decision-making platforms especially with GIS to support faster and more cost-effective decision-making processes. AVMs can estimate the market value of a parcel based on an analysis of the market and the characteristics of the particular group of properties at a specified point in time. Comparing AVMs to the approach suggested in this paper shows that AVMs are more objective, as they predict the land value from the available data of sales, without a direct interaction with the people it seeks to serve, as demonstrated by Branković et al. (2015) and Demetriou (2016b). The AVM is cheaper than the approach suggested in this paper which points to the use of empirical data for each land parcel to determine the value. The suggested approach took 5 working days in an area with a size of 300 hectares, containing 230 farmland parcels. This is opposed to Brankovic et al. (2015) and Demetriou (2016b) who used less than a day for areas of size 6065 and 266 hectares respectively. However, the use of the suggested approach will enable data to be created to form a basis for future modelling of the land values on customary lands in the area.

\section{Conclusion}

This paper set out with the aim to contribute to the approaches for valuing rural customary farmlands without a land market to support land consolidation by developing a framework for a new approach. The five research questions laid out in the introduction were each tackled in the preceding sections. This section provides a summary of the findings and concludes the paper with recommendations.

It was first found that the current methods for valuing customary lands in Ghana only cover urban lands and rural residential lands which are held in leasehold and are registered. Although land mobility is low in rural customary lands, the customs do not necessarily ban the sale and exchange of lands but rather restrict the operation of a land market. It discourages market transactions as lands are held in trust for the next generation, thus reinforcing the need for a valuation approach that will provide a sound basis for comparing the farmlands for exchange. Furthermore, there exists the arrangement where farmers rent out their lands for a nominal flat rate, lending credence to the non-economic view of land in these areas. The standard approaches to valuing land for land consolidation in general were found to be either the market value approach or the agronomic approach. Thirteen valuation factors were found to be relevant to the valuation of rural customary lands for land consolidation, according to the literature. These factors generally fell under two groups, the internal factors that were integral to the farmland parcel and the factors that relate to the outside - the external factors. Under the internal factors, there were the factors related to the physical attributes of the property, the legal conditions inherent and the agricultural productivity. The external group of factors included the locational factors and the planning scheme in the area. Among the identified factors, the local farmers assigned weights according to their importance. The most important factor in the area was found to be the land tenure arrangement. This was followed by the proximity to the town square and the road access. The relevance of the weights assigned to the LVFs was tested with three scenarios where the results of the three different weights were compared to the weights assigned by the local farmers. Here, it was found that the different sets of weights resulted in significant differences in the resulting LVIs which could affect the comparative basis for the farmland parcels. The strength of this approach was found in the transparent and participatory nature, which has been found to give local people a sense of confidence in projects and increases their trust (Asiama et al., 2017c). Furthermore, the local people's view on land value that is incorporated reinforces the ability of the approach to determine the land value the people will agree with. This is needed especially in the land reallocation stage of land consolidation. However, this strength also contributes to its weakness, the direct interaction with the local farmers which is more expensive and time-consuming compared to other studies that advocate the use of AVMs. As the local farmers have little economic regard for the land, it is very important that their perception be ascertained. This notwithstanding, once the suggested approach is used over time, the data can be standardised for comparable areas to enable the modelling of the land values.

Based on the above findings, it is found that there is the need for a further verification for the LVIs that resulted from the case study framework with the local farmers to confirm the LVIs with respect to the farmers' perception of their land values in relation to neighbouring and similar farmland parcels. Further research also needs to be conducted on how this process can fit into land consolidation projects' land reallocation phase, and into the land valuation practices on customary lands in general.

\section{Acknowledgements}

The authors also wish to acknowledge the support of DigitalGlobe Foundation for the provision of the satellite images that were used in the study.

\section{ORCID}

Kwabena Obeng Asiama (D) http://orcid.org/0000-0001$7445-1347$

Rohan Bennett (D) http://orcid.org/0000-0002-1200-2068

\section{References}

Abubakari, Z., et al., 2016. Land consolidation, customary lands, and Ghana's Northern Savannah Ecological Zone: an evaluation of the possibilities and pitfalls. Land Use Policy, 54, 386-398. doi:10.1016/j.landusepol.2016.02.033. 
Anim-Odame, W.K. 2011. Compulsory Acquisition and Compensation in Ghana: Principles and Practice. American Real Estate Society Conference. Seattle, WA: American Real Estate Society.

Arko-Adjei, A. 2011. Adapting Land Administration to the Institutional Framework of Customary Tenure (PhD Thesis). Delft: Delft University of Technology.

Asiama, S.O., 1981. Chieftaincy - a Transcient Institution in Urban Ghana? Sociologus, 31 (3), 122-140.

Asiama, S.O., 2004. Current Changes in Customary/Traditional Land Delivery Systems in Sub-Saharan African Cities - Ghana. In: M Mattingly, and A. Durand-Lasserve, ed. Housing the Poor through African Neo-Customary Land Delivery Systems. London: DFID, $41-57$.

Asiama, K.O. 2015. Governance in Resettlement from Compulsory Land Acquisition and Resettlement: A Case Study of the Bui Dam Project (MSc Thesis). Enschede: University of Twente.

Asiama, K.O., Bennett, R.M., and Zevenbergen, J.A., 2017a. Land consolidation on Ghana's rural customary lands: drawing from The Dutch, Lithuanian and Rwandan experiences. Journal of Rural Studies, 56, 87-99. doi:10.1016/J.JRURSTUD.2017.09.007.

Asiama, K.O., Bennett, R.M., and Zevenbergen, J.A., 2017b. Participatory land administration on customary lands: a practical VGI experiment in Nanton, Ghana. ISPRS International Journal of Geo-Information, 6 (7), 186. doi:10.3390/ijgi6070186.

Asiama, K.O., Bennett, R., and Zevenbergen, J., 2017c. Land consolidation for sub-saharan Africa's customary lands - the need for responsible approaches. American Journal of Rural Development, 5 (2), 39-45. doi:10.12691/AJRD-5-2-2.

Asiama, K.O., Lengoiboni, M., and van der Molen, P., 2017d. In the land of the dammed: assessing governance in resettlement of Ghana's Bui Dam Project. Land, 6 (4), 80. doi:10.3390/land6040080.

Aslan, S.T.A., Gundogdu, K.S., and Arici, I., 2007. Some metric indices for the assessment of land consolidation projects. Pakistan Journal of Biological Sciences: PJBS, 10 (9), 1390-7. Retrieved from http:// www.ncbi.nlm.nih.gov/pubmed/19069948.

Awuah, K.G.B., et al., 2016. An evaluation of property valuation practice in sub-saharan Africa: a case study of Ghana. London: Royal Institute of Chartered Surveyors (RICS). Retrieved from www. rics.org/research.

Beinat, E., 1997. Value functions for environmental management Dordrecht, Netherlands: Springer. doi:10.1007/978-94-015-8885-0.

Boydell, S., 2015. Demystifying the Valuation of Customary Land. In World bank conference on land and poverty2. Washington, DC: The World Bank. Retrieved from https://customarylandsolutions.files. wordpress.com/2016/05/boydell-2015-demystifying-the-valuation-ofcustomary-land-world-bank-land-poverty-conference.pdf

Branković, S., Parezanović, L., and Simović, D., 2015. Land consolidation appraisal of agricultural land in the GIS environment Geodetski Vestnik, 59 (2), 320-334. doi:10.15292/geodetskivestnik.2015.02.320-334

Bullard, R. 2007. Land Consolidation and Rural Development (Papers in Land Management No. 10). Chelmsford.

Clark, C., 1973. The Value of Agricultural Land. New York: Pergamon Press.

Demetriou, D. 2014. The Development of an Integrated Planning and Decision Support System (IPDSS) for Land Consolidation ( $\mathrm{PhD}$ Thesis). Leeds: University of Leeds/Springer.

Demetriou, D., 2016a. A spatially based artificial neural network mass valuation model for land consolidation. Environment and Planning B: Planning and Design, doi:10.1177/0265813516652115.

Demetriou, D., 2016b. The assessment of land valuation in land consolidation schemes: the need for a new land valuation framework. Land Use Policy, 54, 487-498. doi:10.1016/j.landusepol.2016.03.008

Demetriou, D., See, L., and Stillwell, J., 2013. A parcel shape index for use in land consolidation planning. Transactions in GIS, 17 (6) 861-882. https://doi.org/10.1111/j.1467-9671.2012.01371.x.

Demir, H., Gur, M., and Cagdas, V., 2002. Land consolidation, valuation and cadastre. In FIG XXII International Congress. Washington, DC. Retrieved from https://www.fig.net/resources/proceedings/fig proceedings/fig_2002/Js14/JS14_demir_gur_cagdas.pdf

Elias, T.O., 1956. The Nature of African Customary Law. Manchester: Manchester United Press.
FAO, 2008. Opportunities to Mainstream Land Consolidation in Rural Development Programmes of the European Union (FAO Land Tenure Policy Series No. 2). Rome: Food and Agriculture Organisation

GLTN, 2017. Guide to the Valuation of Unregistered Lands - Final Draft. Nairobi. Retrieved from https:/www.gltn.net/index.php/ publications/publications/download/2-gltn-documents/2352-finaldraft-guide-to-the-valuation-of-unregistered-lands.

Gonzalez, X.P., et al., 2004. Evaluation of land distributions with joint regard to plot size and shape. Agricultural Systems, 82 (1), 31-43. Retrieved from http://econpapers.repec.org/article/eeeagisys/v_ 3a82_3ay_3a2004_3ai_3a1_3ap_3a31-43.htm.

Haldrup, N.O., 2015. Agreement based land consolidation - in perspective of new modes of governance. Land Use Policy, 46, 163-177.

Hardin, G., 1968. The Tragedy of the Commons. Science, 162, 12431248. doi:10.1126/science.162.3859.1243.

Hartvigsen, M. 2015. Land Reform and Land Consolidation in Central and Eastern Europe after 1989 - Experiences and perspectives (PhD Thesis). Aarlborg: Aalborg University.

Kasanga, K.R., and Kotey, N.A. 2001. Land management in Ghana: Building on tradition and modernity.

Kidido, J.K., et al., 2015. Who is the rightful recipient of mining compensation for land use deprivation in Ghana? Resources Policy, 43, 19-27. doi:10.1016/j.resourpol.2014.10.004.

Migot-Adholla, S.E., et al., 1991. Indigenous land rights systems in sub-Saharan Africa: a constraint on productivity? The World Bank Economic Review, 5 (1), 155-175. doi:10.1093/wber/ 5.1.155.

Mooya, M.M., 2009. Market value without a market: perspectives from transaction cost theory. Urban Studies, 46 (3), 687-701. https://doi. org/10.1177/0042098008101002.

Netting, R.M., 1972. Of men and meadows: strategies of Alpine land use. Human Ecology, 4, 135-146. doi:10.1007/BF01531217.

North, D. C., 1990. Institutions, institutional change and economic performance. (J. Alt \& D. C. North, Eds.) (The Politi). Cambridge: Cambridge University Press.

Nothale, D.W., 1986. Land tenure systems and agricultural production in Malawi. In: J. W. Arntzen, L. D. Ngcongco, and S. D. Turner, ed. Land Policy and Agriculture in Eastern and Southern Africa. Tokyo: United Nations University. Retrieved from http://archive. unu.edu/unupress/unupbooks/80604e/80604E0h.htm\#Land $\%$ 20 tenure $\% 20$ systems $\% 20$ and $\% 20$ agricultural $\% 20$ production $\% 20$ in $\% 20$ Malawi

Nzioki, N., et al., 2013. Valuation of Unregistered Lands. London: Royal Institute of Chartered Surveyors (RICS). Retrieved from www.rics. org/research.

Rajaonson, J., and Tanguay, G.A., 2017. A sensitivity analysis to methodological variation in indicator-based urban sustainability assessment: a Quebec case study. Ecological Indicators, 83, 122-131. doi:10.1016/j.ecolind.2017.07.050.

RICS. 2017. RICS valuation - Global Standards 2017. Royal Institute of Chartered Surveyors (RICS). Retrieved from http://www.rics.org/ Global/red_book_2017_global_pgguidance_160617_rt.pdf.

Thurston, A.F., 1987. Smallholder Agriculture in Colonial Kenya: The Official Mind and the Swynnerton Plan. Cambridge: African Studies Centre.

Van Dijk, T. 2003. Dealing with Central European land fragmentation: a critical assessment on the use of Western European instruments (PhD Thesis)

van Gils, H., Siegl, G., and Bennett, R., 2014. The living commons of West Tyrol, Austria: lessons for land policy and land administration. Land Use Policy, 38, 16-25. doi:10.1016/j.landusepol. 2013.10.011.

Wyatt, P., 1996. The development of a property information system for valuation using a geographical information system (GIS). Journal of Property Research, 13 (4), 317-336. https://doi.org/10.1080/ 095999196368826.

Zahedi-Seresht, M., Jahanshahloo, G.-R., and Jablonsky, J., 2017. A robust data envelopment analysis model with different scenarios. Applied Mathematical Modelling, 52, 306-319. doi:10.1016/j.apm. 2017.07.039. 